ICONTECH INTERNATIONAL JOURNAL OF SURVEYS, ENGINEERING, TECHNOLOGY

ISSN 2717-7270

Journal homepage: http://icontechjournal.com/index.php/iij

\title{
ERGONOMIC CONDITIONS ASSESSMENT OF A BUS FACTORY
}

Koray AL

Marmara University, Institute of Pure and Applied Sciences, Occupational Safety

Department, Kadikoy, Istanbul

Prof. Dr. Yahya BOZKURT

Marmara University, Faculty of Technology, Metallurgy and Materials Engineering

Kadıkoy, Istanbul

ORCID NO: 0000-0003-1816-5922

\begin{tabular}{|c|c|}
\hline ARTICLE INFO & ABSTRACT \\
\hline $\begin{array}{l}\text { Keywords } \\
\text { Ergonomics } \\
\text { Workforce } \\
\text { Working } \\
\text { Conditions } \\
\text { Work Safety }\end{array}$ & $\begin{array}{l}\text { Eventhough the production technology and capacity have been } \\
\text { improved, manpower is indispensable. Coach production industry is } \\
\text { one of the heavy industries. Production processes are mostly } \\
\text { manpower in addition to automation and mechanization in these } \\
\text { factories. Ergonomics is the one of the most important subject to } \\
\text { increase the production efficiency and job security in heavy industry } \\
\text { factories which use manpower heavily. Ergonomics is the field which } \\
\text { aims to reduce the accidents and job related illnesses, anatomic } \\
\text { problems in human body, psychological and physiological fatigue and } \\
\text { minimize the workforce loss. Ergonomic statement evaluation is } \\
\text { possible with providing ergonomic criteria such as anthrometric, } \\
\text { environmental condition, and work place. } \\
\text { In this study, some experimental studies are done in order to evaluate } \\
\text { the ergonomical conditions in chassis frame production, cataphoresis, } \\
\text { paint shop, assembly, and quality inspection processes. The } \\
\text { experimental studies include static and dynamic anthrometric } \\
\text { measurements on a choosen process and experimental subject workers. } \\
\text { The environmental conditions namely, temperature, humudity, } \\
\text { lightening, air quality, and noise level are periodicly meausured with } \\
\text { proper measuring devices and these data are recorded. The results are } \\
\text { used to make an inference with comparing literature. Furthermore, } \\
\text { inconvenient results are studied in order to determine the relation with } \\
\text { work accidents, work related illnesses and total efficiency parameters } \\
\text { in the factory. This study is considered to be a guidance for the effects } \\
\text { of ergonomical conditions on workplace safety and health, work } \\
\text { accidents and occurences, and production efficiency. }\end{array}$ \\
\hline
\end{tabular}

Received 29 July 2020; Received in revised form 5 August 2020; Accepted 20 August 2020;

Available online 15 September 2020

dai: 10.46291//CDNTECHval4iss2pp35-47 


\section{INTRODUCTION}

Human factor, which is one of the most important factors in industrial development, brought along various problems. One of the most important of these problems is human health. With the determination of the direct relationship between efficiency and human health, a discipline need has been determined that needs to be examined in detail. This need led to the formation of the science of ergonomics. While maintaining employee health, ergonomics also provides an increase in performance. It provides an increase in quality and productivity for businesses. In this study, ergonomic conditions in a bus production factory are analyzed and it is aimed to protect employee health and increase performance depending on the analysis results.

\section{LITERATURE RESEARCH}

Newman Lauand Henry Ma, who has presented approaches for work and performance analysis and has interpreted results based ergonomically, as a result of work, analysis methods and various approaches for ergonomic measurements in the design of workstations have been define.

Ashraf A. Shikdar and Naseem M. Sawaqed investigated occupational health problems in developing countries in their study. By examining the average injury rates, they found that the lack of ergonomic information and communication is due to poor ergonomic conditions. They found that the increase in poor ergonomic conditions also caused various health and safety problems.

People are often not resistant to climatic changes that can lead to changes in body temperatures. Working in heat emitting environments, where the climatic conditions are cold or in cold working environments generally affect work and employee productivity.

Noise can be defined as disturbing sound. It is possible to examine separately as indoor and outdoor noise. One of the most common problems seen in industrial enterprises is hearing loss caused by loud noise. Resulting from the loudness; it is observed that the distraction, motivation and work efficiency of employees decrease.

Vibration is defined as the motion of the objects systematically. Vibration from machinery and equipment generally used in production-oriented enterprises significantly affects employee productivity. The negative effects of vibration on people vary depending on vibration intensity, duration, direction and frequency. While low frequency vibrations do not have a major effect, vibrations usually between 1 and 100 herz create serious health problems. High frequency vertical vibrations cause various health problems such as headaches, balance disorders, numbness and tingling sensations in the fingertips, fatigue, neck, back, arms, chest pain.

In order to be protected from vibration related health problems, it is generally necessary to cover the handles of the hand tools with materials such as rubber and plastic, or to use protective gloves that reduce the exposure to vibration. 
Today, one of the most important problems affecting employee health is dust and toxic substances caused by many substances from production. $70 \%$ of occupational diseases are caused by dust and toxic substances. Powders, largely respiratory function and allergic ailments; toxic substances cause many serious diseases that are carcinogenic and sometimes untreatable until early death.

As a result of various studies, it has been observed that the machine periods due to perception error are perceived as slow in environments with insufficient light and light vibrations. This effect, also called "stroboscopic effect", is due to the fact that the lighting lamps used in the working environment are not correctly selected.

\section{ERGONOMY}

\section{Define of Ergonomy}

The word of ergonomy in ancient Greek, the word work is derived from ergon and the word law is derived from niomos.

Ergonomics is a science with a social and economic purpose. The science of ergonomics examines both the physical and psychological aspects of people, and also provides solutions for the technical and organizational domain.

\section{History of Ergonomy}

The history of ergonomy; It is based on research in ancient scientific fields such as psychological, physiological and engineering. In the literature, the word ergonomics was first used in Poland by Jastrzebowski, W. in 1857. The science of ergonomics emerged in the years of World War II when scientists began to design advanced systems and products. The designed systems and products were created without considering the users. It has been understood that human and environmental factors should also be taken into consideration in order to use the products safely and efficiently. With the determination of people's needs, the science of ergonomics started to develop.

\section{Research of Environmental Conditions in Factory Environment}

The study I have done at the factory on ambient conditions consists of respirable dust measurements, lighting measurements, noise measurements and vibration measurements.

\section{METHODS}

\section{Respirable Dust Measurements}

Respirable dust measurements were made at locations where dust density could be high at the factory. The measurement standard MDHS 14/3 has been adopted. Gravimetric Analysis was applied in the analysis. The air drawn was sampled at a suction rate of $2.21 / \mathrm{min}$ for 120 minutes, and then filtered through a nylon cyclone. During the measurements, Gilian GilAir device was used. 


\section{Lighting Measurements}

In lighting measurements, two different measurement values were calculated, day and night lighting. The standard COSHR / 928-1-IPG-039 was adopted. Measurements 4 measuring areas with a maximum distance of 3 meters between each measuring point were determined indoors. The measurements were started with reference to the point where the lighting source was located, and finished at the edges of the wall. In open area measurements, measurement points were determined as a straight line to indicate the level of illumination according to the length of the areas. 4 measuring points were determined on each measuring point, at least 3 meters between them. Measurements were started from the lowest point of illumination, and ended at the brightest point (under the lighting source). TS EN 12464-1 standards were accepted for indoor areas and TS EN 12464-2 standards for open areas. The limit values of the fields according to the standards are shown in Table 1. Testo 545 brand device was used in the measurements.

Table 1. TS EN 12464 Lighting Limit Values

\begin{tabular}{|c|c|c|c|}
\hline \begin{tabular}{|l|} 
Standard \\
No. \\
\end{tabular} & Referance No. & Job Area or Activity Type & Limits (Lux) \\
\hline \multirow{13}{*}{$\begin{array}{l}\text { TS EN } \\
\text { 12464-1 } \\
\text { (Indoor) }\end{array}$} & 5.1 .1 & $\begin{array}{l}\text { Traffic information, circulation areas and } \\
\text { corridors inside the buildings }\end{array}$ & 100 \\
\hline & 5.1 .4 & Loading ramps \& platforms & 150 \\
\hline & 5.2 .2 & Lounges & 100 \\
\hline & 5.2 .4 & Cloakrooms, Washbasins, Bathrooms, Toilets & 200 \\
\hline & 5.3 .1 & $\begin{array}{l}\text { General areas inside buildings - Control rooms / } \\
\text { Machine rooms, areas with control order }\end{array}$ & 200 \\
\hline & 5.4 .1 & Warehouses & 100 \\
\hline & 5.5 .2 & $\begin{array}{l}\text { General areas inside buildings - Storage areas, } \\
\text { Manned passageways. }\end{array}$ & 150 \\
\hline & 5.18 .3 & $\begin{array}{l}\text { Industrial activities and crafts - Metal work and } \\
\text { processing / Welding }\end{array}$ & 300 \\
\hline & 5.18 .5 & $\begin{array}{l}\text { Industrial activities and crafts - Metal work and } \\
\text { processing / Precision machining, grinding: } \\
\text { tolerances }<0,1 \mathrm{~mm}\end{array}$ & 500 \\
\hline & 5.18 .11 & $\begin{array}{l}\text { Industrial activities and crafts - Metal work and } \\
\text { processing / Rough Assembly }\end{array}$ & 200 \\
\hline & 5.24 .2 & $\begin{array}{l}\text { Vehicle construction and repair / Painting; } \\
\text { spraying room, polishing chamber }\end{array}$ & 750 \\
\hline & 5.24 .3 & $\begin{array}{l}\text { Vehicle construction and repair / Painting; } \\
\text { retouching, inspection }\end{array}$ & 100 \\
\hline & 5.24 .6 & $\begin{array}{l}\text { Vehicle construction and repair / General vehicle } \\
\text { services, repair and testing }\end{array}$ & 300 \\
\hline \multirow{5}{*}{$\begin{array}{c}\text { TS EN } \\
\text { 12464-2 } \\
\text { (Outdoor) }\end{array}$} & 5.1 .1 & Pedestrian walkways & 5 \\
\hline & 5.1 .2 & $\begin{array}{l}\text { Traffic areas (up to } 10 \mathrm{~km} / \mathrm{h} \text { ) for slow-moving } \\
\text { vehicles such as bicycles, trucks and excavating } \\
\text { machines }\end{array}$ & 10 \\
\hline & 5.1 .3 & Regular vehicle traffic (up to $40 \mathrm{~km} / \mathrm{h}$ ) & 20 \\
\hline & 5.7 .1 & $\begin{array}{l}\text { Short-term use of large units and rough } \\
\text { materials, loading and unloading of goods } \\
\text { without solid packaging }\end{array}$ & 20 \\
\hline & 5.9 .1 & $\begin{array}{l}\text { Low traffic, such as parking spaces for shops, } \\
\text { terraced houses and apartments, bicycle parking } \\
\text { spaces }\end{array}$ & 5 \\
\hline
\end{tabular}

Received 29 July 2020; Received in revised form 5 August 2020; Accepted 20 August 2020; 


\section{Noise Measurements}

Noise measurements were made in areas where noise intensity could be the highest. Dosimeters were fixed at the ear level of the employees. TS 2607 ISO 1999 standard was adopted in the measurements. The limit value of the ear protectors used by the employees is $37 \mathrm{~dB}$. Measurements were made with Cirus CR: 110A doseBadge brand measuring device. The limit Page | 39 values taken into consideration when making measurements are shown in table 2.

Table 2. Limit values taken into consideration in noise measurements

\begin{tabular}{|l|c|c|c|}
\hline & MSD (dBA) & EYMED (dBA) & EDMED (dBA) \\
\hline Lex dB(A) & 87 & 85 & 90 \\
\hline PTepe dB(C) & 140 & 137 & 135 \\
\hline
\end{tabular}

\section{Vibration Exposure Measurements}

Vibration exposure measurements were made to hand tool operators and forklift operators. Two different measurement methods ("Whole body vibration exposure" and "Hand-Arm Vibration exposure") were used. TS ISO 2631-1, TS EN 1032 + A1 for whole body vibration exposure, TS EN ISO 5349-1, TS EN ISO 5349-2 standards for Hand-Arm Vibration exposure. 3 consecutive measurements were made on 3 separate axes. Measurements were made with SVAN 958 device.

\section{RESULTS}

15 of the respirable dust measurements made on 15 employees remained below the legal limit of $5 \mathrm{mg} / \mathrm{m}^{3}$ in accordance with the Regulation on Fighting Dust. The measurement results are shown in figure 1. 
Figure 1. Respirable Dust Exposure Measurements

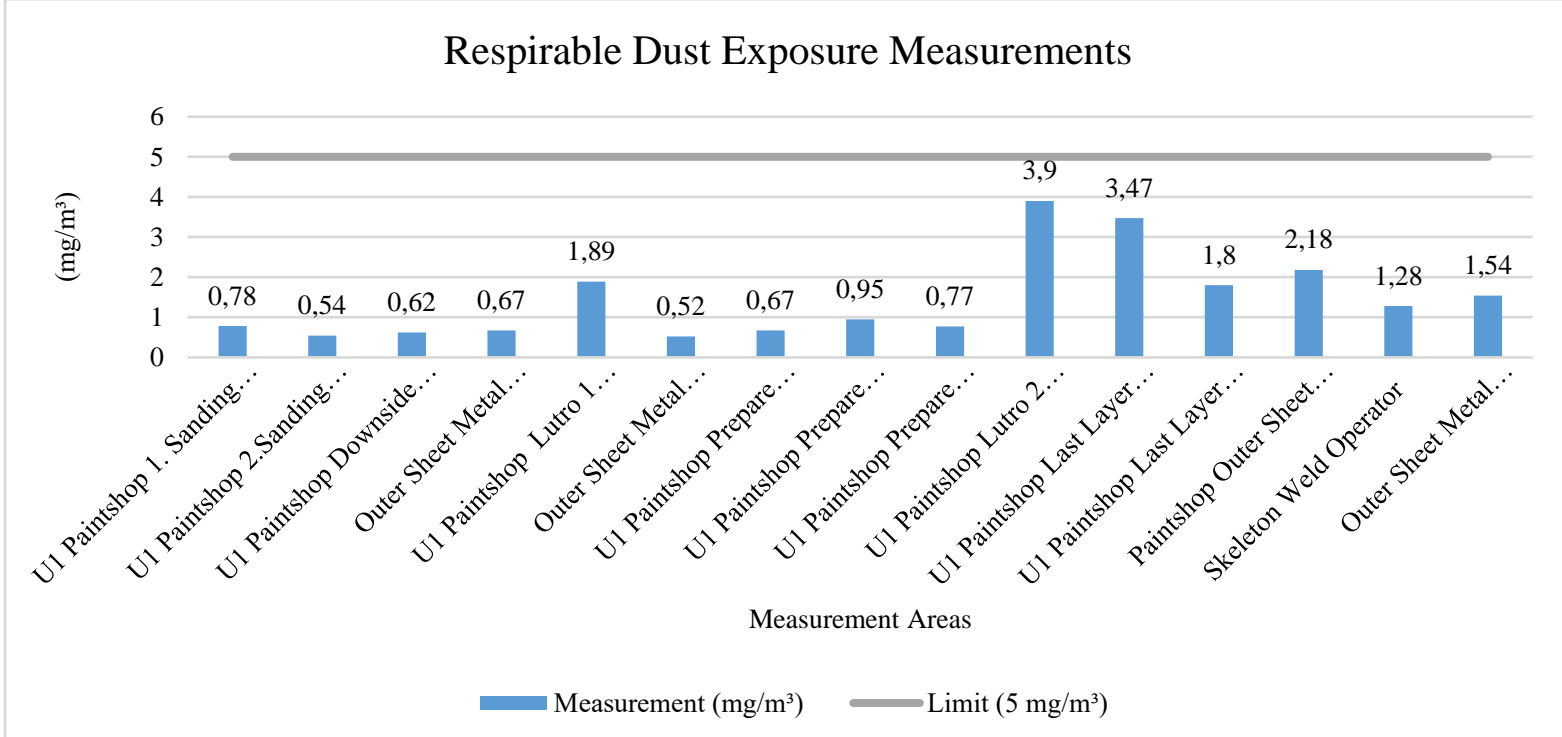

In daytime lighting measurements at 124 different points, illumination below the limit value was detected at 11 different points as shown in Figure 2 and Figure 3. Illumination under the limit value was determined in $8.87 \%$ of the measurement points in daytime lighting measurements.

Figure 2. Daylighting Measurement Areas Under 300 Lux Limit Value

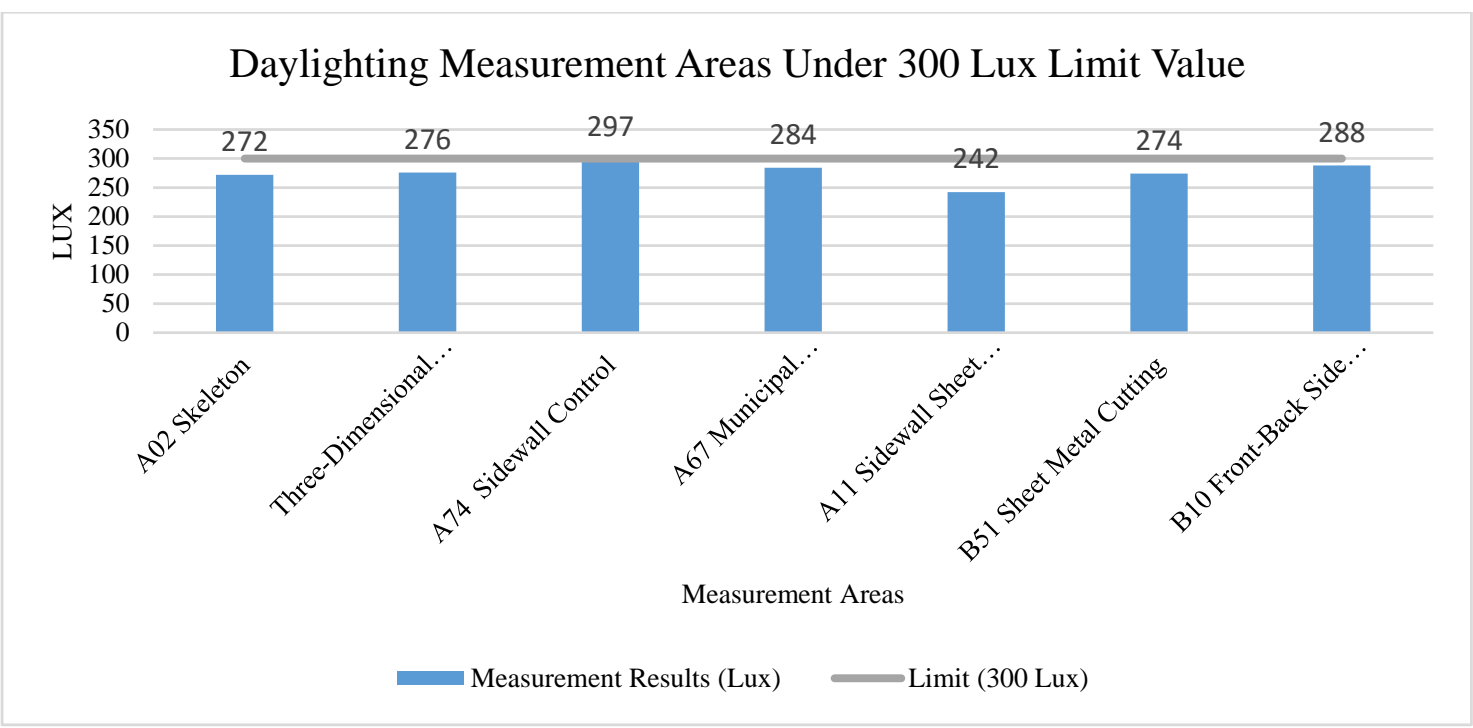

(Skeleton, three-dimensional measurement, sidewall control, municipal sidewall mounting, sheet metal, sheet metal cutting point and front-back cover station) 7 points remained below the limit of 300 lux with a rate of $5.65 \%$. 
Figure 3. Daylighting Measurement Areas Under 750 Lux Limit Value

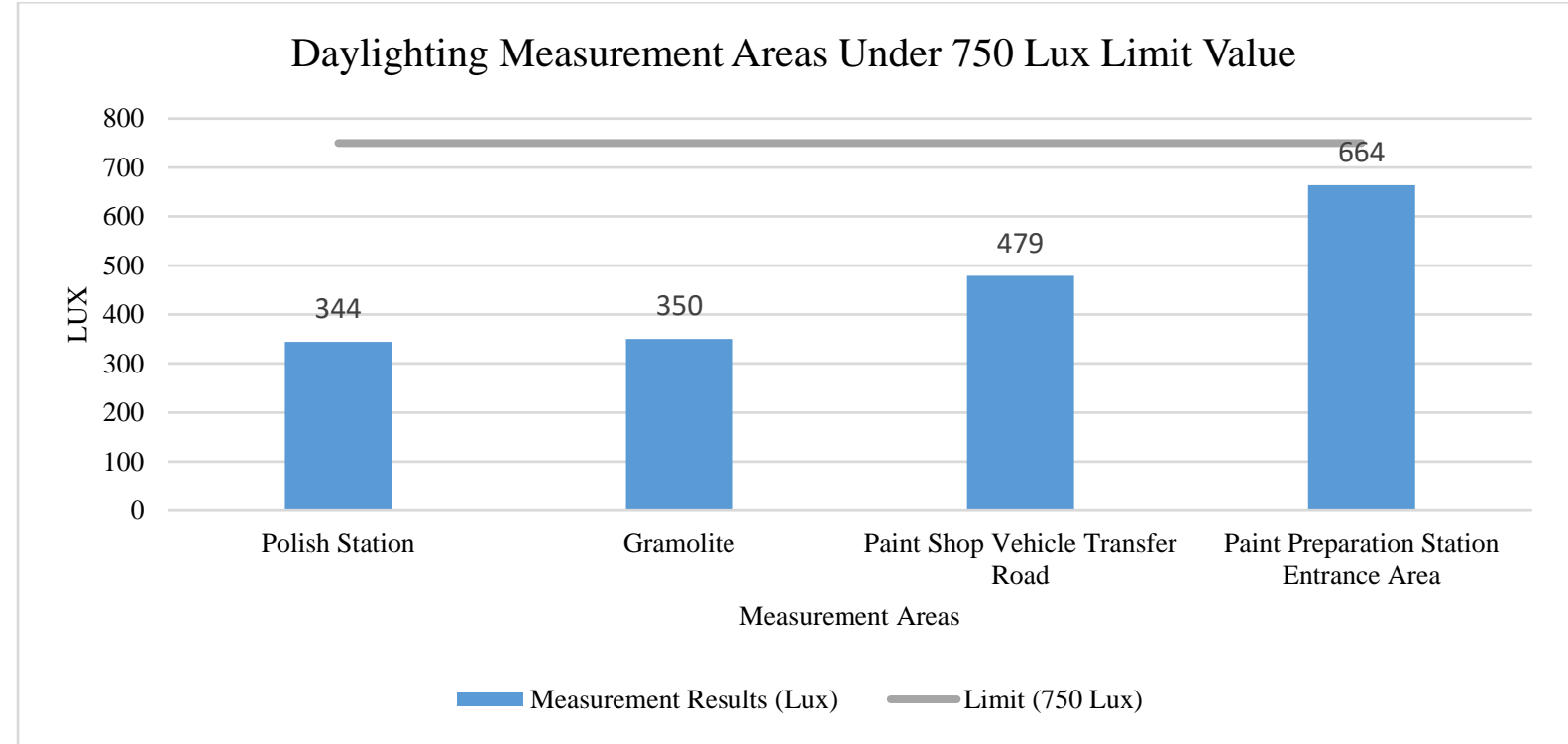

Page | 41

(Polish Station, Gramolite, Paint Shop Vehicle Transfer Road, Paint Preparation Station Entrance Area) 4 points remained below the limit of 750 lux with a rate of 3,23\%.

In night lighting measurements made at 140 different points, as shown in Figure 4 and Figure 5 , illumination below the limit value was detected with a rate of $27.85 \%$ at 39 different points.

Figure 4. Night Lighting Measurement Areas Under 300 Lux Limit Value

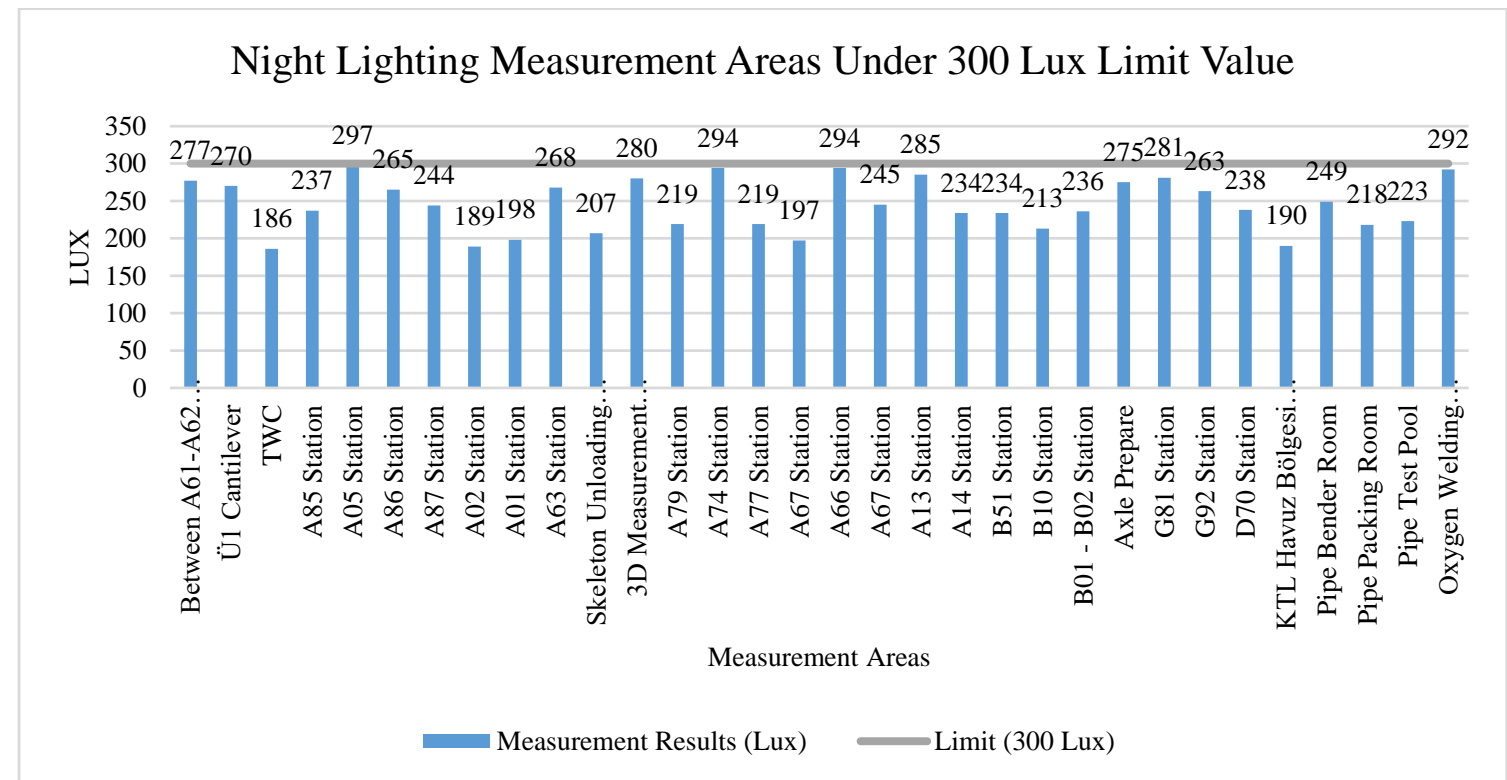

In the lighting measurements made for night lighting, lighting was detected at 32 points of 140 points and at the limit of 300 lux with a rate of $22.86 \%$.

Received 29 July 2020; Received in revised form 5 August 2020; Accepted 20 August 2020;

Available online 15 September 2020

dai: 10.46291//CONTECHvol4iss2pp35-47 
Figure 5. Night Lighting Measurement Areas Under Different Lux Limit Value

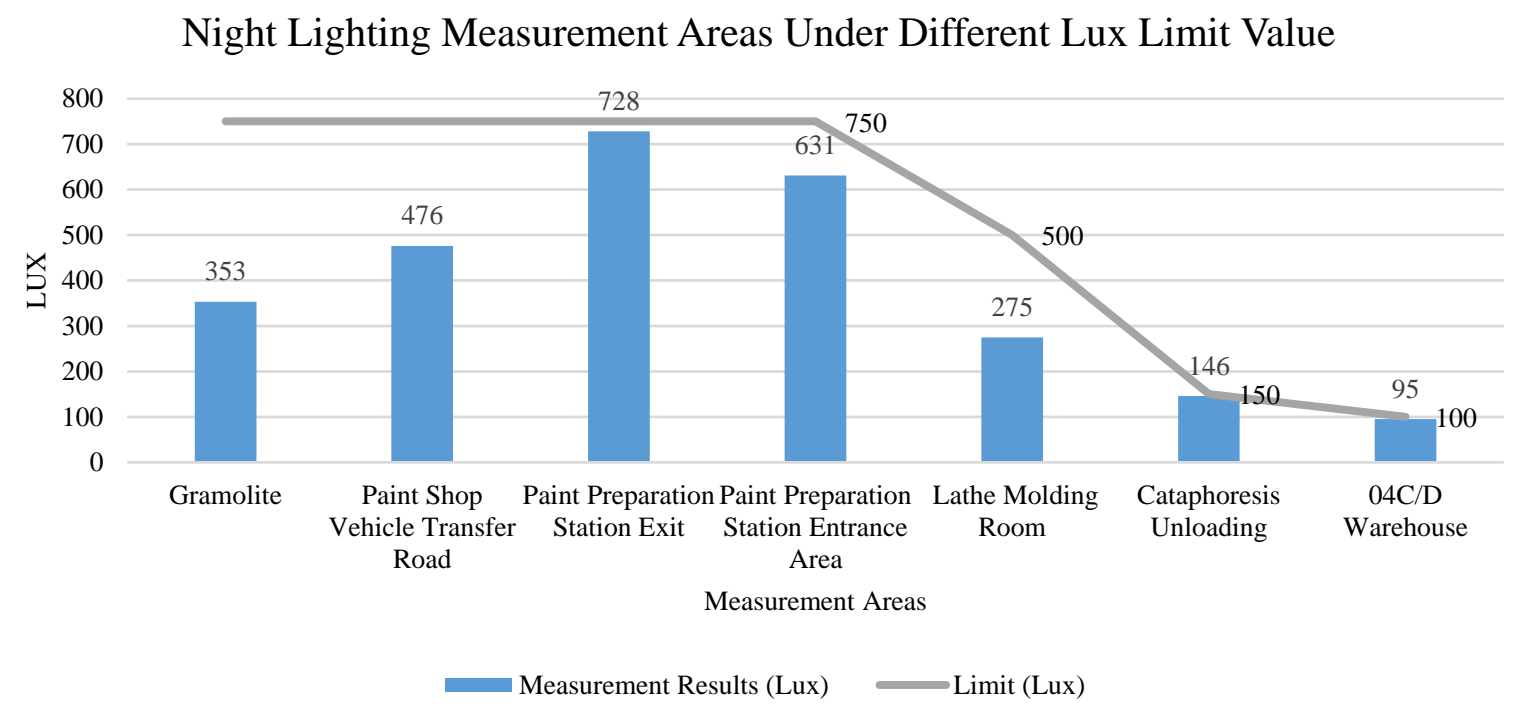

In the lighting measurements made for night lighting, lighting was detected at 7 points of 140 points, at points with different lux limit values with $5 \%$ ratio, under the limit value.

As a result of the studies, it has been determined that there are points that cannot be opened for natural lighting. It was decided to add additional lighting systems to the areas below the limit value in day and night lighting measurements.

Noise measurement results at 77 different points; shows that Figure 6 the 8-hour noise exposure values of 49 employees with a ratio of $63.64 \%$ are above the legal limit. MSD (87dBA), EYMED (85dBA) ve EMED(80dBA) standards taken into consideration.

Figure 6. Noise Exposure Values on Over Limit Values

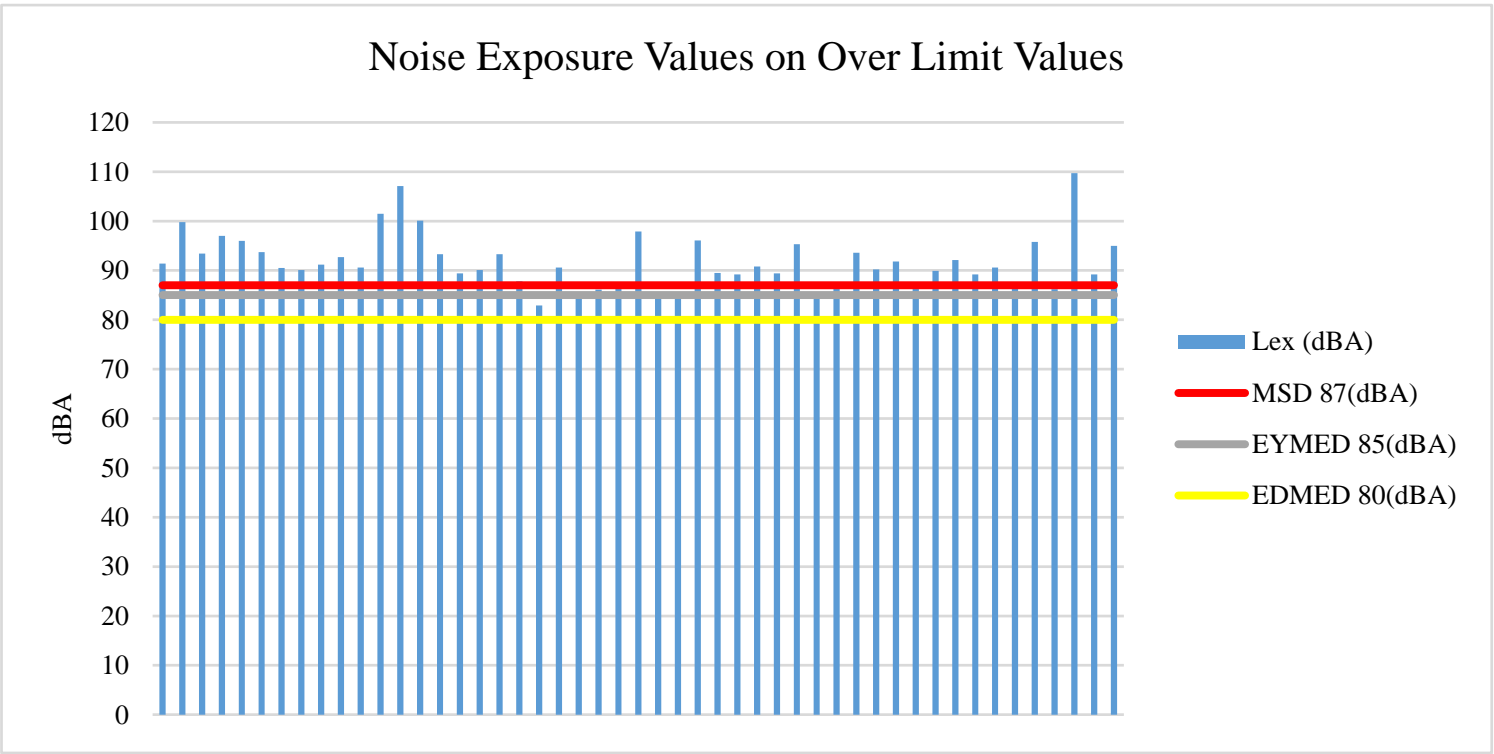

result of the measurements at the same point in 77, the highest noise value where 60 employees

Received 29 July 2020; Received in revised form 5 August 2020; Accepted 20 August 2020;

Available online 15 September 2020

dai: 10.46291//CONTECHvol4iss2pp35-47 
remained above the legal exposure limit values with a rate of $77.9 \%$ over an 8 hour period is shown in Figure 7. Measurements were evaluated considering MSD (140dBC), EYMED (137BC) and EMED (135dBC) standards.

Figure 7. Maximum Noise Exposure Values on Over Limit Values

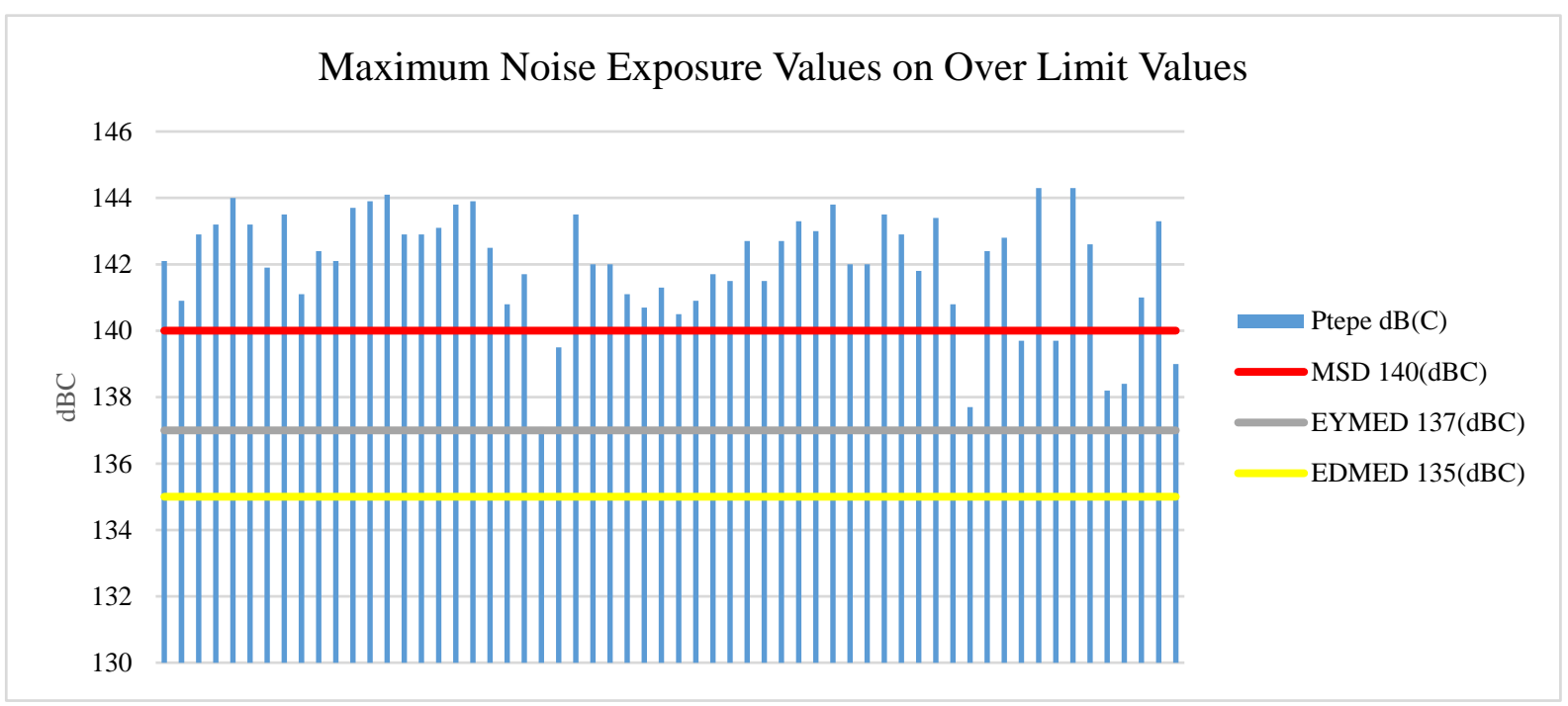

Ear-protective equipments are given to all personnel on first day of work and routine inspections are made. The personnel, who remain below the limit in the measurements, are also obliged to have their ear protective equipment with them. Necessary information was sent to the managers. Routine inspection frequency has been increased at these points of the factory.

In the vibration exposure measurements made on 29 employees consisting of forklift operators, air sanding operators, planing operators, jigsaws operators and pneumatic impact wrenchgun operators, vibration exposure above the limit value was detected in 14 employees with a ratio of $48.3 \%$ as seen in figure 8 . 
Figure 8. Vibration Exposure Values on Over Limit Values

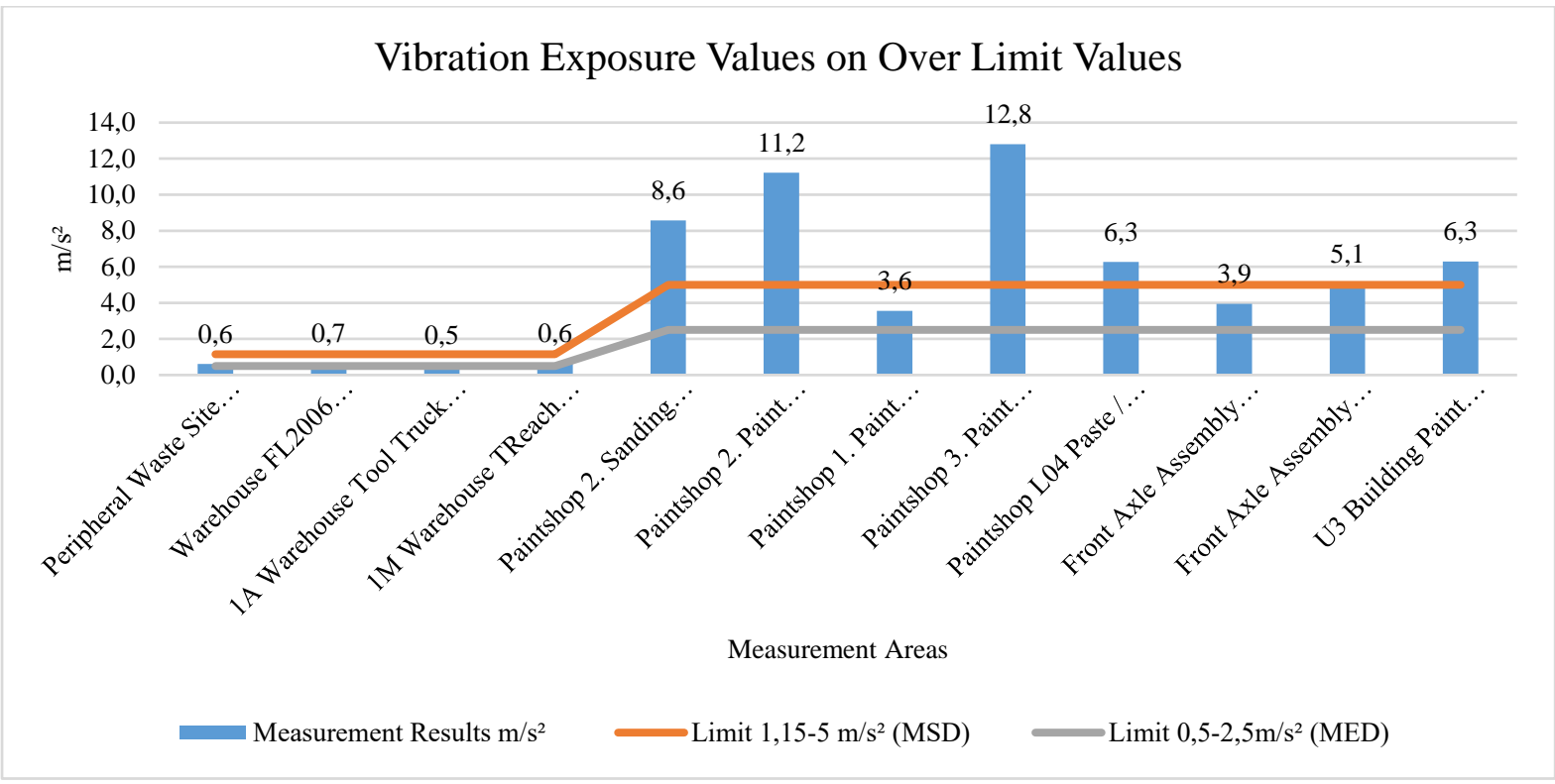

4 of the 14 employees consist of forklift operators. Forklift operators make up $13.8 \%$ of the 29 personnel with a total measurement. Body vibration exposure measurements were made in these employees. $34 \%$ other 10 operators; Since there are operators using hand tools, hand-arm vibration exposure measurements were made.

The results were shared with the occupational safety unit and team leaders. A meeting was held on measures to be taken. According to the meeting's decision, it was decided to use antivibration gloves. With the condition that the employees will work at the same station, it was decided to work with one hand during the assembly of 1 vehicle, and then the rotation with the use of gloved hand tool during the installation of 1 vehicle. In this way, it is aimed to reduce the exposure during the 8-hour study. In order to reduce the exposure of forklift operators, working times were regulated. Accordingly, it was determined that extra forklift operator will be employed in 2020. Thus, it is aimed to reduce the 8-hour exposure times of forklift operators.

\section{REFERENCES}

Lau, N. and Ma, H., (2007) "Reconstructing motion data for evaluation in design process", International Association of Societies of Design Research, The Hong Kong Poly Technic University.

Shikdar, A. A., and Sawaqed, N. M., "Ergonomics, and occupational health and safety in the oil industry: a managers' response", Computers \& Industrial Engineering 47, 223-232, (2004).

Erkan,N.,1997.Ergonomi. M.P.M Yayınları, Yayın No: 373, Ankara.

Barlı, Ö., 1998. Tr. J. of Agriculture and Forestry, TÜBİTAK, 22, 521-524.

Arıc1, K., 1999. İşçi Sağlığı ve İş Güvenliği. Sargın Ofset, Ankara.

Received 29 July 2020; Received in revised form 5 August 2020; Accepted 20 August 2020;

Available online 15 September 2020

dai: 10.46291//CDNTECHval4iss2pp35-47 
Akal, Z., 1991. İș Etüdü. M.P.M Yayınları, Yayın No: 29, 4. Basım, Ankara.

Akyöney, B., 2003. Temizlik Hizmetleri İşletmeciliği. Detay Yayıncılık, Ankara.

Ç. Güler.Ergonomiye Giriş. Ankara Tabip Odası Yayını, 2001, Ankara

Kıraç, Y., "Büro yönetiminde ergonomi ve ergonominin verimliliğe etkisi: Ankara Emniyet Müdürlüğü'nde bir uygulama",Yüksek Lisans Tezi, Gazi Üniversitesi Eğitim Bilimleri

Enstitüsü, Büro Yönetimi Anabilim Dal1, Ankara, (2005).

Koçak, G., "Gemi makineleri işletmesinde ergonomik analiz", Yüksek Lisans Tezi, İstanbul Teknik Üniversitesi Fen Bilimleri Enstitüsü, İstanbul, (2007).

Dul, J. and Neumann, W.P., Ergonomics contributions to company strategies, ERIM Report Series Research in Management, (58), (2008).

Baslo, M., "Ofis ergonomisi- sırt ve boyun ağrılarını önlemek için ofis ortamını düzenlemek", İ.Ü. Cerrahpaşa Tıp Fakültesi Sürekli Tıp Eğitimi Etkinlikleri, Baş, Boyun, Bel Ağrıları Sempozyum Dizisi No:30, 155-165, ( 2002).

TS EN 12464 Işık ve Işıklandırma İş Mahallerinin Aydınlatılması

Çalışanların gürültü ile ilgili risklerden korunmalarına dair yönetmelik https://www.resmigazete.gov.tr/eskiler/2013/07/20130728-11.htm

Tozla Mücadele Yönetmeliği Resmi Gazete (5 Kasım 2013) [online] https://www.resmigazete.gov.tr/eskiler/2013/11/20131105-9.htm

Allendorf, K., \& Ghimire, D. (2012). Determinants of marital quality in an arranged marriage society. Population Studies Center Research Reports, 12-758, USA.

[1]Yavuzkan, G. (2015) Ergonomi Risk Analizleri Yazılımlaştırılması Ergonomi - İş Sağlığı Güvenliği Risk Haritalandırılması, Süleyman Demirel Üniversitesi Mühendislik Bilimleri ve Tasarım Dergisi 3(3), Ergonomi, s.603-614, ISSN: 1308-6693.

Seçkiner, S., Kurt, M. (2004) Ofis Güvenliğinin Değerlendirilmesi İçin Geliştirilmiş Ergonomi Teknolojisi : Kairos, Örnek Uygulama. Gazi Üniv. Müh. Mim. Fak. Der. Cilt 19, No 1, s.3741.

Mandıracıoğlu, A. (2001) Çalışma Ortamında Maruziyetin Değerlendirilmesi, 8.Ergonomi Kongresi Bildiri Kitabı, s.86-87.

OHSA (1999) Health and Safety Guidelines for VDU in the Workplace.

Türkiye İstatistik Kurumu İşgücü İstatistik Verileri (Şubat2018) http://www.tuik.gov.tr/HbPrint.do?id=27688

Bridger, R. S. (1995) Introduction to Ergonomics, McGraw-Hill Inc, New York 
Karl, K., Henrike, K., \& Kroemer, K. (2000). Ergonomics: How to Design for Ease and Efficiency (2nd Edition). New Jersey: Prentice Hall.

Sanders, M. , S. , McCormick, E.J. (1992) Human Factors in engineering and design, 7th. Ed. McGraw-Hill Inc, New York

Sabancı, P. D. (1989). Ergonomi ve Tarihsel Gelişim. 2. Ulusal Ergonomi Kongresi Bildiriler Kitabı (s. 20-28). içinde Adana.

Kaya, M.D., Güzel, D. ve Çubukçu, B. (2011) "Ilıca şeker fabrikası çalışanlarının iş memnuniyeti, ergonomik çalışma koşulları ve iş stresi yönünden incelenmesi”, Atatürk Üniversitesi İktisadi ve İdari Bilimler Dergisi, Cilt: 25, Say1: 2.

Uyan, M. K. (2018) "İş Sağlığı ve Güvenliği [online]”, http://www.isveguvenlik.com/ergonomi/ergonomi.html.

Yalçınkaya, Ö. (2014) Dokuz Eylül Üniversitesi Kişisel Sayfalar. Dokuz Eylül Üniversitesi [online] http://kisi.deu.edu.tr/ozgur.yalcinkaya/endmuh.html

Erkan, N. (1997) Ergonomi, M.P.M. Yayınları No: 373, Genişletilmiş Dördüncü Baskı, Ankara. Ünsal, P. (1998) Ergonomi, İstanbul Üniversitesi Yayın No: 4112, Edebiyat Fakültesi Yayın No: 3411, Edebiyat Fakültesi Basımevi, İstanbul.

Erkan, N. (1988) “Ergonomi: Verimlilik, Sağlık ve Güvenlik için İnsan Faktörü Mühendisliği”, MPM Yayınları, Ankara

Turan, D. (2007) "Endüstri İşletmelerinde Günlük İş Yaşamında Uygulanan Ergonomi Metotlarının İncelenmesi”, Yayınlanmamış Yüksek Lisans Tezi. İstanbul Ticaret Üniversitesi Fen Bilimleri Enstitüsü.

Milli Prodüktivite Merkezi, (2005) Verimliliği Artırıcı Yaklaşım ve Teknikler Dizisi, MPM Yayınları

Gunning, J., Eaton, J., Ferrier, S., Frumin, E., Kerr, M., King, A. and Maltby, J., (2001), Ergonomic handbook for the clothing industry, Kanada: Thistle.

International Labour Organization, (17 Kasım 2011), "Your health and safety at work ergonomics [online]", http://actrav.itcilo.org/actrav-english/telearn/osh/ergo/ermain.htm

Yenigün, N. D. (2006) "Bir montaj masasında iş akışının ergonomik analizi ve iyileştirme önerileri”, Yüksek Lisans Tezi, Uludağ Üniversitesi Fen Bilimleri Enstitüsü, Makine Mühendisliği Anabilim Dalı, Bursa.

Tunay, M., Melemez, K. ve Dizdar, E. N. (2006) “Ormanc1lıkta kullanılan yükleme makinaları operatör koltuklarının antropometrik tasarımı”, Teknoloji, Cilt 9, Sayı 2, 137-144.

Armağan, K. (2003) "Büro verimliliğinin tesis edilmesinde ergonomik tasarımın önemi", Yüksek Lisans Tezi, Dumlupınar Üniversitesi Sosyal Bilimler Enstitüsü, İşletme (yönetim organizasyon) Anabilim Dalı, Kütahya. 
Yeow, P. H. P. and Sen, R. N. (2003) "Quality, productivity, occupational health and safety and cost effectiveness of ergonomic improvements in the test workstations of an electronic factory", International Journal of Industrial Ergonomics 32,147-163.

Yavuz, U., Bakan, U. (30 Ekim 2011) "Türkiye'de web tabanlı haber sitelerinin tasarım ve ergonomi düzeylerinin karşılaştırmalı analizi”, Sanat Dergisi, http://edergi.atauni.edu.tr/index.php/gsfd/article/viewFile/6274/5977.

Human Factors and Ergonomics Society, (2 Ekim 2011) "Educational Resources, Definitions of Human Factors and Ergonomics [online]" http://www.hfes.org/Web/EducationalResources/HFEdefinitionsmain.html.

Shikdar, A. A., and Sawaqed, N. M. (2004) "Ergonomics, and occupational health and safety in the oil industry: a managers' response", Computers \& Industrial Engineering 47, 223-232.

Duyar, İ., (1995) "İnsanın fiziksel boyutlarındaki değişmeler ve ergonomik açıdan önemi“, 5. Ergonomi Kongresi: (180-189), Ankara Üniversitesi.

Su, B. A. (2001) Ergonomi, Pano Ofset Yayınları, Ankara.

Özok, A.F. (1981) Türk Sanayi İşçileri Üzerine Antropometrik Bir Araştırma, Doğa Bilim Dergisi, Cilt 5

Altıparmak, R.S. (2006) "Ülkemiz insan antropometrisine uygun mutfak mobilyası tasarımı için veri bankasının oluşturulması ve bir uygulama”, Bilim Uzmanlığı Tezi, Zonguldak Karaelmas Üniversitesi Fen Bilimleri Enstitüsü, Mobilya ve Dekorasyon Eğitimi Anabilim Dalı, Karabük 